\title{
Appendiceal Carcinoma pTX TNM Finding v8
}

National Cancer Institute

\section{Source}

National Cancer Institute. Appendiceal Carcinoma pTX TNM Finding v8. NCI Thesaurus. Code C134055.

Appendiceal carcinoma in which the primary tumor cannot be assessed. (from AJCC 8th Ed.) 